\title{
The Role of the Employees in the Jordanian Universities Students' Affairs Deanships in Attracting Students towards Participating in Activities
}

\author{
Omar T. Batayeneh ${ }^{1}$ \\ ${ }^{1}$ Faculty of Arts, Hashemite University, Zaerqa, Jordan \\ Correspondence: Omar T. Batayeneh, Faculty of Arts, Hashemite University, Zarqa 133024, Jordan. Tel: \\ 962-795-449-967. E-mail: omar@hu.edu.jo
}

Received: August 26, 2013

Accepted: September 12, 2013 Online Published: November 20, 2013

doi:10.5539/res.v5n5p205

URL: http://dx.doi.org/10.5539/res.v5n5p205

\begin{abstract}
The present study aimed at investigating the role of deanships of students affairs of Jordanian universities in encouraging students participation in university activities. The sample of the study consisted of all employees (242) working at deanships of students affairs in three official universities in Jordan (Yarmouk, Hashemyia and Mu'ta) during the second semester of the academic year 2009-2010. Results of the study indicated that universities deanships of students affairs play a significant role in encouraging students participations in universities activities as indicated in participates responses on the study instrument. In addition results showed that there were no significant differences between employee's role in encouraging student's participation in university activities that can be attributed to gender, years of experience and academic qualification. However, differences were only found based on student's socioeconomic status for the favor of the Hashemite University.
\end{abstract}

Keywords: role of employers, Jordanian universities, students

\section{Introduction}

Universities usually demonstrate an evident interest in the activities that are available for their students so as to enable them practice several skills rather than the formal curriculum stated by the courses and its restricted goals, and that is usually achieved through affecting every aspect of their students' lives during the years they spend inside the university campus. Thus, these universities have varied their students' activities in accordance to their human and financial capabilities to include more aspects that match more of the students' desires, abilities and interests. Universities believe that these activities are necessary, and consider them a complement and an enhancement for the experiences students are exposed to inside and outside the lecture room, so they include the following types of activities: sporting activities of all types and its requirements like buildings, playgrounds, public utilities as well as coaches and supervisors who are well-prepared for their duties, and cultural activities where they can have theatres, issue newspapers and magazines and hold seminars. Also, there are artistic activities where they focus on painting studios, galleries and orchestras. Another type is the scientific activities that require laboratories where students practice their hobbies, and express their creative abilities. Consequently, universities have employed competent workers so as to apply their various activity programs.

If our social, cultural, educational and youth organizations are required nowadays more than before to assume a guiding role that exceeds the traditional one, universities must receive the most important part to perform a role that doesn't only involve transforming knowledge for teaching the youth, but also changing and helping students develop in all aspects of their characters. The role also includes helping students realize their mental status, form mature personalities and acquire self-confidence so as to obtain a good mental health. Consequently, they will be able to see life positively and that helps them quickly get rid of the bad mood when facing any negative situation in life without being occupied by their own opinions. That could achieve the normal consistency that helps students achieve individual, group and humanistic self-realization (Al-Zu'bi et al., 2004).

The university is considered to be responsible for preparing specialized people for different scientific fields. It is also responsible for the cultural preparation and supplying them with high levels of social responsibility and ethical decency. So its responsibility exceeds the role of preparing students scientifically to what is more comprehensive. It entails building the comprehensive human thought, instilling the values of truth and virtue as 
well as providing them with proper self-expression skills. In order for the university to accomplish that, the educational process should be widened to include the practical side of the student's life which is related to knowledge and different sciences, the emotional side that is related to ethical decency, values and mental health, and the cognitive side for the purpose of forming the rational personality that is aware of different life aspects (Al-Toom, 2003).

Universities established some extra curricular activities that go side by side with the academic curricula and complement them for the purpose of developing and polishing the students' personalities. These activities are varied, religious, social, cultural, scientific, artistic, sportive and other types so students could benefit during their free time at the university. Also, universities have allocated budgets and procured the needed managerial, technical and human supplies for the implementation of these activities. Besides, they ensured a number of university seats and scholarships for the distinguished students in these activities (Deerani, 2003).

Currently, the students' activeness represents a fundamental part of the educational-instructional process in many countries. Also, the concept of activeness has developed to meet the students' needs in different aspects: scientific, physical, spiritual, entertaining, social and mental (Bodi, 2003).

The students' interaction with their teachers and their colleagues through lectures and free time activities is considered a major procedure that helps in polishing their personalities and incorporating into the university community that includes male and female students from different regions and social groups. Thus, the university becomes crucible where social, sectarian, and tribal differences melt, and the national unity emerges (Al-Farhan, 2000).

The role of the deanships' workers is great in attracting and drawing more students to participate in different activities, and that is closely connected to the fact that these workers should be aware of their career's features and its requirements. That diversity requires well-prepared facilities and public utilities in order to get fruitful activities that have positive impact. So we have to search for a distinguished employee for the students' affairs deanship who can assume that important role and contribute to the preparation of the strategic plan for the deanship's activities. He should also be able to translate successfully these plans and visions into a tangible reality among students. For that purpose, the deanship's plan should include diverse activities, and should have a special open-handed budget so that it can promote and compete externally and internally. All of that demands understanding, support and encouragement from the university's administration for both the activities and their philosophy, and that would be motivating for the workers for more enthusiastic and eager application for the activities.

Generally, the role of the students' affairs deanship appears in attracting and guiding students towards practicing different activities that accompany the curriculum for the sake of investing their free time and developing the aspects of their characters. Hence, it is important to investigate the role of the deanship's employees in attracting students towards participating in their activities after providing them with suitable and relevant facilities, environment and locations for their activities so they can invest their time wisely.

Based on what has been mentioned, it is clear that the students' activities and the employees working on them assume a prominent role in achieving the needed positive changes for our students, such as acquiring new skills, improving their social relations, modifying their attitudes and polishing their personalities.

Al-Shra'a et al (2010) discovered that the influence of some factors of Jordanian universities' students' participation in activities was medium for most of the tool items in the study. The findings revealed that there are no statistically significant differences for the influence of some variables upon students' participation in activities ascribed to the variables of (gender, place of living, the family's income, the student's education level, and the university). Besides, the study showed the existence of statistically significant differences for the influence of some variables on the students' participation in activities ascribed to the variable of college and for the benefit of humane colleges.

The results of Al-Bataine et al (2008) indicated that there is an impact in all of the fields for the role of practicing the sportive activities on polishing the university student personality, and that impact affected the total average of the fields. Also, the findings revealed the influence of some variables (gender, family income, place of living, the type of activity, and the students' marks average) on the students' participation in the university activities. On the other hand, it showed that there is no effect for the variables of (university and level of education) on the students' participation in the university activities.

The study of Al-Zu'bi et al (2007) stated the order of the fields as follows: the area of facing up to the social problems, the area of entertaining the university students, the area of university students' psychological troubles, 
the area of university students' health troubles, and the area of university students' academic performance. The findings indicated that there are differences among male and female students for the benefit of male ones, differences for the benefit of human colleges' students, and differences for the benefit of students who got (very good) averages and the $4^{\text {th }}$ year students. That was related to the effect of practicing activities on facing up to some students' problems from the point of view of Hashemite University students according to some variables.

Deerani's (2003) came to the idea that students ascribe the reasons for abandoning participating in different students' activities to the studying causes and to the organizational procedures for these activities, not to personal causes. Regarding the studying causes or reasons, the findings of the study revealed significant differences ascribed to the variable of gender and place of living for the benefit of students who live outside the university hostel. Whereas regarding the personal causes, the study got to some differences ascribed to the variable of total average for the benefit of students whose averages are beyond 2 points, and the variable of nationality for the benefit of native female students. Regarding the studying causes, there were statistically significant differences ascribed to the variable of education level for the benefit of $4^{\text {th }}$ year students, and the variable of college for the benefit of students of the college of Science.

Al-Zyood's \& Aranki's (2003) revealed a number of troubles students usually face like lack of variation in activities, limited number of activities and lack of adequate facilities for students. The results of this study indicated the existence of differences between male and female students for the benefit of male ones in their participation in activities, but it didn't come up with any differences between the B.A students and Diploma students in the percentage of their participation in activities.

Al-Sukhun (2001) stated that male students practice activities more than female students within the domain of sportive activities, playing cards, as well as visiting internet cafes and cinemas. On the other hand, female students surpassed the male students in activities like reading, household duties, sitting at home, and listening to radios. The study also showed that students from high-income families usually like the activities of sitting in cafes and going for a drive, whereas low-income students usually tend to watch TV and have household duties. Besides, students of scientific colleges succeeded in practicing sportive activities as well as staying at home and cafes, whereas students of literary colleges succeeded in the activities of reading, watching TV and doing household duties.

Holloway's (2002) revealed the most important reasons for students' participation in activities which were the spiritual encouragement presented to the students participating in the activities and the good relationship among the students themselves and among the persons who are in charge of these activities, as well as the students' loyalty for their colleges and universities.

Tinto (1998) stated that the most important reasons that make students abandon the university activities are represented by the academic difficulties such as heavy-load duties and students' hour-load during the semester, the adaptation difficulties, the financial difficulties and lack of clarity in the activities' goals.

Marr (1989) came up with the result that free time activities clearly indicate that the student enjoys adventuresome and entertainment, consequently it recommended that students should be guided towards practicing the activities during their free time as a strategy for dealing with shyness and introversion.

Butler (1988) said that new students who took part in curricula or extra curricular activities surpassed the students who didn't participate. The character of those students developed significantly, and that was shown through improving their missions, developing their independence, developing their goals and building mature personalities during the year.

\section{The Problem of the Study}

The research problem was to identify the role of the workers in Students' Affairs Deanships at the Jordanian universities in attracting students towards participating in activities. Specifically, this study attempts to answer 2 questions:

1. Is there a role for the workers in Students' Affairs Deanships at the Jordanian universities in attracting students towards participating in activities?

2. Does this role of the workers in Students' Affairs Deanships at the Jordanian universities in attracting students towards participating in activities differ according to: gender, university, scientific qualification and years of experience? 


\section{The Importance of the Study}

This study aims at identifying the role of the workers in Students' Affairs Deanships at the Jordanian universities in attracting students towards participating in activities, as well as investigating if there is a difference for the role according to (gender, university, scientific qualification and years of experience) in attracting students towards participating in activities. The findings of this study are expected to add some pieces of information that would increase knowledge related to this field, as well as helping Jordanian universities' executives in identifying the actual situation practiced at deanships towards students so as to reveal positives and reinforce them and decrease negative points.

\section{The Method \& Procedures}

\subsection{The Population and the Sample of the Study}

The community of the study included the workers at the formal Jordanian universities' deanships. The sample included all the workers at the formal Jordanian universities' deanships (Yarmouk University, Hashemite University and Mu'tah University) during the second semester of the year 2011/2012, with a total of (242) employees.

\subsection{The Instrument of the Study}

To achieve the goal of the study, the researcher developed the tool of the study after examining the available literature regarding this field as well as conducting some interviews with experienced people working at deanships in different Jordanian universities. Some notes and suggestions were recorded regarding this subject so as to develop the tool of the study. Then, the researcher distributed an open questionnaire among a sample of the deanships' workers (the study community) with a total of (100) questionnaire, including 2 open questions:

1. what are the most important factors that contribute to students' participation in deanships' activities?

2. what are the most important factors that contribute to students' abandoning the deanships' activities?

After checking answers, they were transferred into items where each one implies a factor. The answers of the random sample helped in building some items that are related to the study's subject. Accordingly, the items were formulated, merged and categorized, then fields and initial items were identified in the questionnaire. Later, the tool was examined by a group of referees specialized in education and a group of deanships' workers who have a long experience in this domain.

In light of the referees' notes about some items which have low-level connection with the questionnaire items, these items were replaced by new logically-valid items, and the final version of the questionnaire ended up with (60) items distributed among 3 domains.

Lickert's fivefold scale was utilized as follows: (5) grades for the very high degree of agreement, (4) grades for the high degree of agreement, (3) grades for the medium degree, (2) grades for the little degree, and (1) grade for the very little degree of agreement.

\subsection{The Stability of the Tool}

The stability was achieved using the method of testing and retesting, within a period of 2 weeks among a group of (45) male and female deanships' workers. The tool's total stability coefficient was (0.83), and for the purpose of increasing the accuracy of the tool's stability, the researcher calculated the interior consistency coefficient using (Cronbach-Alpha) formula. The stability of the entire test was (0.9485), and that level was considered significant and adequate for the purposes of this study.

\subsection{The Procedures for Correcting the Tool of the Study}

In order to correct the tool of the study, the researcher divided the students' answers into 3 levels: high (more than 3.5), medium (2.5-3.49) and low (less than 2.49), knowing that the alternatives for answers are divided into 5 levels: very high ( 5 grades), high ( 4 grades), medium ( 3 grades), little ( 2 grades) and very little ( 1 grade).

\subsection{The Statistical Processing}

In order to answer the study's questions, the researcher used the following statistical processing: means, standard deviations, percentages, t-test, one-way Anova and L.S.D test so as to identify the differences between averages.

\section{Results \& Discussion}

Question 1: Is there a role for the workers in Students' Affairs Deanships at the Jordanian universities in attracting students towards participating in activities? 
To answer this question, means and standard deviations were calculated for the answers of the sample members on each item in the tool according to the field the item belongs to. Results related to this question are displayed for each field individually, the for the study as a whole. Tables $(1,2,3,4)$ clarify the means and the standard deviations for the sample answers.

Table 1. The means, standard deviations and agreement degree for the study sample regarding the items of the first domain

\begin{tabular}{|c|c|c|c|c|c|}
\hline $\begin{array}{l}\text { Item } \\
\text { No. }\end{array}$ & The item & rank & mean & $\mathrm{SD}$ & $\begin{array}{l}\text { Degree of } \\
\text { agreement }\end{array}$ \\
\hline 22 & $\begin{array}{l}\text { Students' participation in activities enables them to build and } \\
\text { develop new friendships. }\end{array}$ & 1 & 4.25 & 0.69 & high \\
\hline 10 & $\begin{array}{c}\text { Students' participation in activities builds up their leading } \\
\text { characters. }\end{array}$ & 2 & 4.23 & 0.88 & high \\
\hline 58 & $\begin{array}{l}\text { Students' participation in activities is considered a mean for } \\
\text { dealing with shyness and introversion. }\end{array}$ & 3 & 4.18 & 0.75 & high \\
\hline 49 & $\begin{array}{l}\text { Students' participation in activities instills in them the } \\
\text { principle of loyalty towards country. }\end{array}$ & 4 & 4.17 & 0.87 & high \\
\hline 40 & $\begin{array}{l}\text { Students' participation in activities builds up the spirit of } \\
\text { debate and respect of other's opinions. }\end{array}$ & 5 & 4.10 & 0.86 & high \\
\hline 55 & $\begin{array}{l}\text { Students' participation in activities instills in them the love } \\
\text { of cooperation and team work. }\end{array}$ & 6 & 4.09 & 0.83 & high \\
\hline 43 & $\begin{array}{l}\text { Students' participation in activities encourages them to } \\
\text { follow distinguished students so as to be like them. }\end{array}$ & 7 & 4.05 & 0.83 & high \\
\hline 4 & $\begin{array}{l}\text { Students' participation in activities enables them to be aware } \\
\text { of other rich social experiences. }\end{array}$ & 8 & 4.03 & 0.97 & high \\
\hline 46 & $\begin{array}{l}\text { Students' participation in activities enables them to become } \\
\text { lovable persons. }\end{array}$ & 9 & 4.01 & 0.85 & high \\
\hline 7 & $\begin{array}{l}\text { Students' participation in activities enables them to visit } \\
\text { different places (inside and outside). }\end{array}$ & 10 & 4.01 & 0.95 & high \\
\hline 31 & $\begin{array}{c}\text { Students' participation in activities is a chance to remove } \\
\text { differences between genders. }\end{array}$ & 11 & 3.98 & 0.87 & high \\
\hline 25 & $\begin{array}{l}\text { Students' participation in activities satisfies their needs, } \\
\text { hobbies and capabilities. }\end{array}$ & 12 & 3.97 & 0.82 & high \\
\hline 16 & $\begin{array}{l}\text { Students' participation in activities teaches them patience, } \\
\text { persistence and tolerance. }\end{array}$ & 13 & 3.96 & 0.90 & high \\
\hline 37 & $\begin{array}{l}\text { Students' participation in activities helps in removing social } \\
\text { differences between students. }\end{array}$ & 14 & 3.91 & 0.90 & high \\
\hline 34 & $\begin{array}{l}\text { Students' participation in activities reinforces elimination of } \\
\text { ethical, regional, partisan and racial instincts. }\end{array}$ & 15 & 3.61 & 1.22 & high \\
\hline 19 & $\begin{array}{c}\text { Students' participation in activities helps them realize and } \\
\text { understand other's troubles. }\end{array}$ & 16 & 3.56 & 0.91 & high \\
\hline 13 & $\begin{array}{l}\text { Students' participation in activities enables them to become } \\
\text { famous figures. }\end{array}$ & 17 & 3.56 & 0.92 & high \\
\hline 1 & $\begin{array}{l}\text { Students' participation in activities enables them to get closer } \\
\text { to the university decision makers. }\end{array}$ & 18 & 3.51 & 0.97 & high \\
\hline 52 & $\begin{array}{l}\text { The society's limitations are obstacles that hinder students' } \\
\text { participation in activities. }\end{array}$ & 19 & 3.31 & 1.09 & medium \\
\hline 28 & $\begin{array}{l}\text { Students' participation in activities mainly results from their } \\
\text { families' encouragement. }\end{array}$ & 20 & 3.08 & 1.05 & medium \\
\hline \multicolumn{3}{|c|}{ The entire average for the field } & 3.88 & 0.90 & high \\
\hline
\end{tabular}

The results displayed in table (2) show that the students' answers on the 1st domain items have high degrees of agreement for the role of the workers in attracting students towards participating in activities, with an averages ranging from (4.25) as the highest level to (3.08) as the lowest. The item of (Students' participation in activities 
enables them to build and develop new friendships.) got the first rank with an average of (4.25), whereas the item of (Students' participation in activities builds up their leading characters.) got the second rank with an average of (4.23). Then comes the item of (Students' participation in activities is considered a mean for dealing with shyness and introversion.) which got the third rank with an average of (4.18).

The researcher ascribes that result to the idea that workers believe that students' activities have a great role within the social domain in building new friendships among the students' community both internally and externally, which in turn positively affects the students' relationship with the workers. Thus, students participating in activities become more open-minded and more aware of the benefits of this participation which helps in building friendships and connections related to their active participation and commitment to these programs within a reasonable range permissible in the university. Besides, workers assert that students' activities have the greatest role in building up, developing and polishing the university student's personality to fit the new generation as well as training them for different circumstances through taking part in different activities, programs and experiences provided by the students' affairs deanships. Consequently, this participation positively affects the social side of the student's university life. In addition, the deanships' workers are the closest group dealing with students because of their acquaintance with them, so they can share students in activities for the purpose of dealing with students' shyness and introversion. As a result, the students' inner thought is evoked, and they start expressing different ideas and discussing them with others fearlessly and without hesitation. Hence, these activities have a positive impact in getting rid of students' shyness and introversion because the participant student's personality is usually stronger than others as he/she is exposed to different practical situations that require different reactions.

Through looking at the items that have achieved the first three ranks within the social domain related to workers, we can notice that they are connected with the students in general and with the participant students as well. The students' participation influences them in polishing their leading characters, helping them get rid of shyness and introversion, and being able to respond to others using the generation's thoughts, debate and democracy. That would lead to establishing unique social relationships with other colleagues.

The item of (Students' participation in activities mainly results from their families' encouragement.) got the last rank with an average of (3.08), and the item of (The society's limitations are obstacles that hinder students' participation in activities.) had the rank before the last with an average of (3.31), whereas the item of (Students' participation in activities enables them to get closer to the university decision makers.) got the $18^{\text {th }}$ rank with an average of (3.51). The researcher ascribes that to the fact that students practice the activities with no influence from the family. Today's students take part in activities without consulting their parents because at this period students usually search for independency in life both for their present time and their future.

Workers assert that the society's traditions, limitations and values don't have a role in preventing students from participating in activities since students have a deep desire for giving up lots of the society's limitations. Also, there is no role for students' participation in activities in getting them closer to executives in the university. Looking at the items that occupied the last three ranks, we can notice that they are connected to each other since students participate in activities without considering their families' opinions or the society's limitations. Also, they don't care for their participation's reflection on the relation with the university executives.

Table 2 clearly shows that this domain has high degrees of agreement for the role of the workers in attracting students towards participating in activities since it got means that ranges from (4.18) as the highest level to (2.74) as the lowest. The item of (Students' participation in activities is a good chance to make use of free time.) got the first rank with an average of (4.18), whereas the item that got the second rank was (The availability of facilities and needs for the activities encourages students to participate.) for an average of (4.05). Then comes the item of (The availability of qualified technical people encourages students to participate in activities.) at the third level with an average of (4.05). 
Table 2. The means, standard deviations and agreement degree for the study sample regarding the items of the second domain

\begin{tabular}{|c|c|c|c|c|c|}
\hline $\begin{array}{l}\text { Item } \\
\text { No. }\end{array}$ & The item & rank & mean & SD & $\begin{array}{l}\text { Degree of } \\
\text { agreement }\end{array}$ \\
\hline 32 & $\begin{array}{l}\text { Students' participation in activities is a good chance to make } \\
\text { use of free time. }\end{array}$ & 1 & 4.18 & 0.83 & high \\
\hline 26 & $\begin{array}{l}\text { The availability of facilities and needs for the activities } \\
\text { encourages students to participate. }\end{array}$ & 2 & 4.05 & 0.83 & high \\
\hline 29 & $\begin{array}{l}\text { The availability of qualified technical people encourages } \\
\text { students to participate in activities. }\end{array}$ & 3 & 4.05 & 0.89 & high \\
\hline 8 & $\begin{array}{l}\text { Students' participation in activities widens their future } \\
\text { horizons. }\end{array}$ & 4 & 4.1 & 0.83 & high \\
\hline 47 & $\begin{array}{l}\text { The university rewards the distinguished students } \\
\text { participating in activities. }\end{array}$ & 5 & 3.97 & 1.08 & high \\
\hline 59 & $\begin{array}{l}\text { The availability of scholarships for the excellent participants } \\
\text { in activities encourages more students to take part. }\end{array}$ & 6 & 3.93 & 1.09 & high \\
\hline 50 & $\begin{array}{l}\text { The availability of more facilities, incentives and free } \\
\text { transport attracts more students to take part. }\end{array}$ & 7 & 3.86 & 1.08 & high \\
\hline 11 & $\begin{array}{l}\text { Student's participation in activities enables them to get their } \\
\text { exceptional university seats (sporting excellence, artistic,...). }\end{array}$ & 8 & 3.76 & 1.00 & high \\
\hline 41 & $\begin{array}{l}\text { Lack of financial allocations for the activities programs } \\
\text { prevents students from practicing. }\end{array}$ & 9 & 3.75 & 0.94 & high \\
\hline 14 & $\begin{array}{l}\text { Students' participation in activities is sometimes hindered by } \\
\text { lack of equipment or supplies. }\end{array}$ & 10 & 3.59 & 0.95 & high \\
\hline 56 & $\begin{array}{l}\text { The availability of a reward system that guarantees } \\
\text { decreasing the university fees enables more students to take } \\
\text { part in activities. }\end{array}$ & 11 & 3.54 & 1.42 & high \\
\hline 53 & $\begin{array}{l}\text { The availability of a special medical insurance system } \\
\text { increases the number of participants. }\end{array}$ & 12 & 3.52 & 1.22 & high \\
\hline 5 & $\begin{array}{l}\text { Students' participation in activities increases their chances of } \\
\text { getting financial and moral support. }\end{array}$ & 13 & 3.46 & 1.09 & medium \\
\hline 17 & $\begin{array}{l}\text { Lack of constructions decreases students' participation in } \\
\text { university activities. }\end{array}$ & 14 & 3.43 & 1.05 & medium \\
\hline 35 & $\begin{array}{l}\text { The university's closeness to students' home increases their } \\
\text { participation chances. }\end{array}$ & 15 & 3.41 & 1.10 & medium \\
\hline 20 & $\begin{array}{l}\text { The students' financial troubles and difficulties hinder their } \\
\text { participation. }\end{array}$ & 16 & 3.33 & 1.02 & medium \\
\hline 44 & $\begin{array}{l}\text { Lack of transport costs between the university and my } \\
\text { residence decreases the students' participation in activities. }\end{array}$ & 17 & 3.29 & 1.10 & medium \\
\hline 23 & $\begin{array}{l}\text { Students' participation in activities increases their chances of } \\
\text { getting jobs at university after graduation. }\end{array}$ & 18 & 3.19 & 1.11 & medium \\
\hline 38 & $\begin{array}{l}\text { I think that the students' activities are economically useless } \\
\text { for the student. }\end{array}$ & 19 & 2.83 & 1.27 & medium \\
\hline 2 & $\begin{array}{l}\text { Students' participation in activities is restricted by the } \\
\text { family's income. }\end{array}$ & 20 & 2.74 & 1.08 & medium \\
\hline \multicolumn{3}{|c|}{ The entire average for the field } & 3.60 & 1.04 & high \\
\hline
\end{tabular}

The researcher ascribes that to the fact that the role of the workers is clear enough since students who take part in activities try to make use of their free time in doing useful activities that positively affect them either they are social, cultural, or sportive activities. The more the university provides participants with equipments, needs and facilities, the more the students take part in these activities. That is considered one of the factors that attracts more participants to take part which consequently decreases the financial load for students either for buying equipments or tools for activities. Thus, distinguished students in all activities domains need technically and scientifically qualified persons to lead them and guide them towards participating in activities that positively affect their lives. These people must be well-qualified and have high technical capabilities to be able to do 
something. That would definitely reflects on the participants in that they can get different rewards as a result of the proper guidance they will get for organizing their practice time and the interest in academic performance. Through looking at the items that got the first three ranks within the economic domain, we can see that they are connected to each other. They entail the availability of technically-qualified crew who is able to lead and guide students properly with more focus on the academic side so as to preserve and protect the students' future and to make use of their abilities after organizing their free times to participate in the activities. That is closely related to the crew's ability to exploit the facilities and tools provided by the university to decrease the students' financial loads. The item of (Students' participation in activities is restricted by the family's income.) occupied the last rank with an average of (2.74), whereas the item of (I think that the students' activities are economically useless for the student) took the one before the last rank with an average of (2.83). The $18^{\text {th }}$ rank which marked an average of (3.19) was for the item of (Students' participation in activities increases their chances of getting jobs at university after graduation.). The researchers ascribes that to the unavailability of a clear impact for the family's income on the students' participation in activities. The knowledge and experiences of the deanships' workers during the previous years assert that there are no financial benefits for students as a result of their participation in university activities. It is possible that this opinion appeared because universities don't provide the participant students with financial incentives. Also, the university job vacancies have become controlled by other considerations. Besides, our Jordanian universities have become overcrowded with employees. On the other hand, the items that got the last three ranks within the economical domain regarding the workers clearly indicate that there is an obvious economic vision on the level of the participation reflection on the students' personal interests in that it takes the family's circumstances into account and the economic advantage for this participation as well as the possibility of getting a job at the university after graduation.

Table 3. The means, standard deviations and agreement degree for the study sample regarding the items of the third domain

\begin{tabular}{|c|c|c|c|c|c|}
\hline $\begin{array}{l}\text { Item } \\
\text { No. }\end{array}$ & The item & rank & mean & $\mathrm{SD}$ & $\begin{array}{l}\text { Degree of } \\
\text { agreement }\end{array}$ \\
\hline 42 & $\begin{array}{c}\text { My participation in activities develops my field intelligence } \\
\text { the mental aspects. }\end{array}$ & 1 & 4.11 & 0.79 & high \\
\hline 21 & $\begin{array}{l}\text { Students' participation in activities enables them to listen to } \\
\text { new ideas. }\end{array}$ & 2 & 4.07 & 0.78 & high \\
\hline 9 & $\begin{array}{l}\text { Students' participation in activities develops their value of } \\
\text { time respect. }\end{array}$ & 3 & 4.07 & 0.86 & high \\
\hline 33 & $\begin{array}{l}\text { I participate in activities for entertainment and to lessen the } \\
\text { daily life pressure tensions. }\end{array}$ & 4 & 4.01 & 0.80 & high \\
\hline 15 & Students' participation in activities extends their knowledge. & 5 & 4.01 & 0.87 & high \\
\hline 48 & $\begin{array}{c}\text { Inconsistency between the activities' time and lectures time } \\
\text { hinders students' participation. }\end{array}$ & 6 & 3.78 & 0.94 & high \\
\hline 30 & $\begin{array}{l}\text { Academic loads and assignments decreases students' } \\
\text { participation. }\end{array}$ & 7 & 3.75 & 0.94 & high \\
\hline 36 & $\begin{array}{l}\text { Student's participation in activities makes them happy which } \\
\text { positively affects their studying. }\end{array}$ & 8 & 3.67 & 0.95 & high \\
\hline 45 & $\begin{array}{c}\text { Being afraid of getting low marks prevents me from } \\
\text { participating. }\end{array}$ & 9 & 3.59 & 0.96 & high \\
\hline 51 & $\begin{array}{c}\text { Lack of interest and coordination between concerned parties } \\
\text { prevents me from participating. }\end{array}$ & 10 & 3.55 & 1.01 & high \\
\hline 18 & $\begin{array}{l}\text { Lack of technically-qualified and specialized crews hinders } \\
\text { students' participation. }\end{array}$ & 11 & 3.42 & 1.11 & medium \\
\hline 54 & $\begin{array}{l}\text { My participation in the activities brings me closer to my } \\
\text { professors which positively impacts my performance. }\end{array}$ & 12 & 3.28 & 1.12 & medium \\
\hline 6 & $\begin{array}{l}\text { Students' participation in activities negatively affects their } \\
\text { relations with university teachers. }\end{array}$ & 13 & 3.17 & 1.06 & medium \\
\hline 60 & $\begin{array}{l}\text { My participation in activities contributes to my academic } \\
\text { success and facilitates getting a scholarship. }\end{array}$ & 14 & 3.17 & 1.16 & medium \\
\hline 3 & Students' participation in activities negatively affects their & 15 & 3.15 & 0.97 & medium \\
\hline
\end{tabular}




\section{marks average.}

27 The students' affairs deanships track the participant students' academic affairs.

12 Students' participation in activities meets the suitable encouragement and appreciation from teachers.

57 My participation in activities guarantees my academic success.

39 I don't have enough free time to participate in activities.

24 The participant students' academic achievement is better than others'.

The entire average for the field

$\begin{array}{cccc}16 & 3.14 & 1.25 & \text { medium } \\ 17 & 3.13 & 1.04 & \text { medium } \\ 18 & 3.11 & 1.13 & \text { medium } \\ 19 & 2.98 & 1.15 & \text { medium } \\ 20 & 2.84 & 0.95 & \text { medium } \\ & 3.50 & 0.99 & \text { high }\end{array}$

Results displayed in table 3 indicate that this domain has got an equal distribution for the degree of agreement between high and medium for the role of the workers in attracting students to take part in activities. It got averages that range from (4.11) as the highest to (2.84) as the lowest. The item of (My participation in activities develops my field intelligence the mental aspects) got the $1^{\text {st }}$ rank, whereas the item (Students' participation in activities enables them to listen to new ideas) got the $2^{\text {nd }}$ rank.

The researcher ascribes that result to the reason that developing intelligence and mental capacity is the most important benefit of practicing students' activities. That would positively affect the academic achievement since it entails useful experiences for the participants like being exposed to various experiences that stimulate many ideas which lead to creativity that positively impacts the academic aspect. The amount of experiences students are exposed to enables them to get used to different situations and provides them with chances to know other communities from which they can be inspired with useful ideas and thoughts that affect their present and future. That would definitely help participants benefit from new ideas and use them in their academic life. Hence, the existence of student activities' specialized programs and students' commitment for application increase the students' sense of responsibility for time and help in making them more aware of the value of time in order to organize their own life and their own time, and that will consequently have a positive impact on their academic achievement. The first three items within the academic domain regarding the workers are consistent with each other in that participating in different indoor and outdoor activities motivate students to be distinguished and mature which would lead to field intelligence and ideas' renewal and variousness. All of that is related to the students' ability to organize and respect time without neglecting the academic side which is the core of their university life. The item (The participant students' academic achievement is better than others'.) took the last rank with an average of (2.84), whereas the item of (I don't have enough free time to participate in activities.) occupied the one before the last rank with an average of (2.98). Then comes the $18^{\text {th }}$ rank item (My participation in activities guarantees my academic success.) which has got an average of (3.11).

The researcher ascribes that to the reason that there is no effect for the students' participation in activities on their academic achievement as it is not necessarily for the participant student to have a mark average higher than the others. The deanships' workers' knowledge and experience as well as their knowledge of students' lecture programs assert the existence of free time for students which has to be used properly in beneficial programs that positively influence their personalities. These programs also assert that the state of alienation many students may live is mainly because of their inability to adjust to the university life. For all of that, the students' activities played a prominent role in attracting students, and influenced these participants through regulating their lives. Hence, the workers assert that there is no influence for the academic success on the students' participation since this practice requires students' ability to organize their free time according to the activities' time without affecting the academic side. It also entails that students' awareness of their proper time arrangement to participate in activities positively affects their academic life.

Table 4. Means \& Standard deviations for the participants' answers on the whole domains

\begin{tabular}{ccccccc}
\hline Domain No. & domain & rank & Items' No. & mean & SD & Degree of agreement \\
1 & Social & 1 & 20 & 3.88 & 0.46 & High \\
2 & Economic & 2 & 20 & 3.60 & 0.42 & High \\
3 & Academic & 3 & 20 & 3.50 & 0.40 & High \\
& Total & & 60 & 3.66 & 0.37 & High \\
\hline
\end{tabular}


Results displayed in table (5) indicate that all the domains items got a high degree of agreement for the role of the workers in attracting students towards participating in activities. Also, the entire degree of agreement for the domains was high. The social domain obtained the first rank and the highest mean (3.88), an a standard deviation of (0.46), whereas the economic domain occupied the second rank where it got an average of (3.60) and a standard of (0.42). The last rank was given to the academic domain with an average of (3.50) and standard of (0.40). The entire mean for all domains came with an average of (3.66) and a standard of (0.37) as well as a high degree of agreement. Based on what has been mentioned and on the findings displayed in table (5), the results clearly indicate that all of the averages values for the study domains have had a high degree of agreement that ranged from (3.50) to (3.88). Also, the value of the total average was (3.66) with a high degree of agreement. Thus, the social field took the first rank with an average of (3.88), followed by the economic filed that had a mean of (3.60), and finally the third rank for the academic domain for an average of (3.50).

The researcher sees the reason for such a conclusion in that the university students have got a lot of free time, and they look for spending that time in a useful way that positively affects their academic achievement. Also. They like to improve and foster the social aspects of their relation with their colleagues as well as enhancing the relation with the university employees especially those working at deanships.

Results related to question (2):

Does this role of the workers in Students' Affairs Deanships at the Jordanian universities in attracting students towards participating in activities differ according to: gender, university, scientific qualification and years of experience?

To answer this question, it has been divided into 4 sub questions:

First: Does this role of the workers in Students' Affairs Deanships at the Jordanian universities in attracting students towards participating in activities differ according to gender?

To answer this question, means, standard deviations and t-test were calculated, and table 5 shows the means, standard deviations and t-test results for the role of the deanships' workers in attracting students towards participating in activities according to the variable of gender

Table 5. Means \& SDs \& T statistical values for the participants according to gender

\begin{tabular}{llllllllc}
\hline Domain No. & domain & male & \multicolumn{3}{c}{ female } & t-value & Level of significance & significance \\
& & mean & SD & mean & SD & & & \\
\hline 1 & Social & 3.87 & 0.47 & 3.89 & 0.45 & 0.193 & 0.847 & insignificant \\
2 & Economic & 3.60 & 0.41 & 3.59 & 0.45 & 0.174 & 0.862 & insignificant \\
3 & Academic & 3.49 & 0.40 & 3.51 & 0.40 & 0.360 & 0.720 & insignificant \\
Total & & 3.66 & 0.38 & 3.66 & 0.37 & 0.143 & 0.887 & insignificant \\
\hline
\end{tabular}

We can see in the results mentioned in table (6) the following: regarding the first field (the social), the mean was (3.87) and an SD of (0.47) for male students, whereas the female students' mean was (3.89) and an SD of (0.45). It is also clear that there were no significant differences at the level of $(\alpha \leq 0.05)$ for this domain according to the variable of gender.

Regarding the second domain (the economic), the mean reached (3.60) and the SD was (0.41) for male students, whereas the female's mean reached (3.59) with an SD of (0.45). Also, this field has had no significant differences. The third academic domain was also statistically insignificant where the mean was (3.49) for male students and (3.51) for female. Besides, the entire total for all the study domains was insignificant at the level of $(\alpha \leq 0.05)$. The findings indicated no statistically significant differences for the variable of gender within the domains of the study (social, economic and academic) since the significance level in the social field was $(0.847)$, the economic field (0.862), and the academic field (0.720), and the entire significance level was (0.887).

The researcher ascribes that to the notion that deanships' workers seek to attract as many students as possible to participate in activities regardless of their gender. The deanship's plans and programs provide students with activities that attract both male and female students. Thus, deanships' employees try to organize various activities regardless of the worker's gender since the purpose of their job is to attract as many students as possible to take part in the activities. 
Second: Does this role of the workers in Students' Affairs Deanships at the Jordanian universities in attracting students towards participating in activities differ according to the variable of university?

To answer this question, One-Way ANOVA was used to determine the existence of statistically significant differences for the role of deanships' workers in attracting students towards participating in activities according to the variable of university.

Table 6. Means \& SDs for the participants' answers according to university

\begin{tabular}{|c|c|c|c|c|c|c|c|}
\hline \multirow{2}{*}{$\begin{array}{c}\text { Domain } \\
\text { No. }\end{array}$} & \multirow[t]{2}{*}{ domain } & \multicolumn{2}{|c|}{ Yarmouk } & \multicolumn{2}{|c|}{ Hashemite } & \multicolumn{2}{|c|}{ Mu'tah } \\
\hline & & mean & SD & mean & SD & mean & SD \\
\hline 1 & Social & 3.87 & 0.44 & 3.94 & 0.50 & 3.85 & 0.46 \\
\hline 2 & Economic & 3.62 & 0.46 & 3.74 & 0.44 & 3.51 & 0.36 \\
\hline 3 & Academic & 3.41 & 0.39 & 3.57 & 0.41 & 3.53 & 0.40 \\
\hline & Total & 3.87 & 0.44 & 3.94 & 0.50 & 3.85 & 0.46 \\
\hline
\end{tabular}

Table 7. Results of one-way Anova for the sample according to university

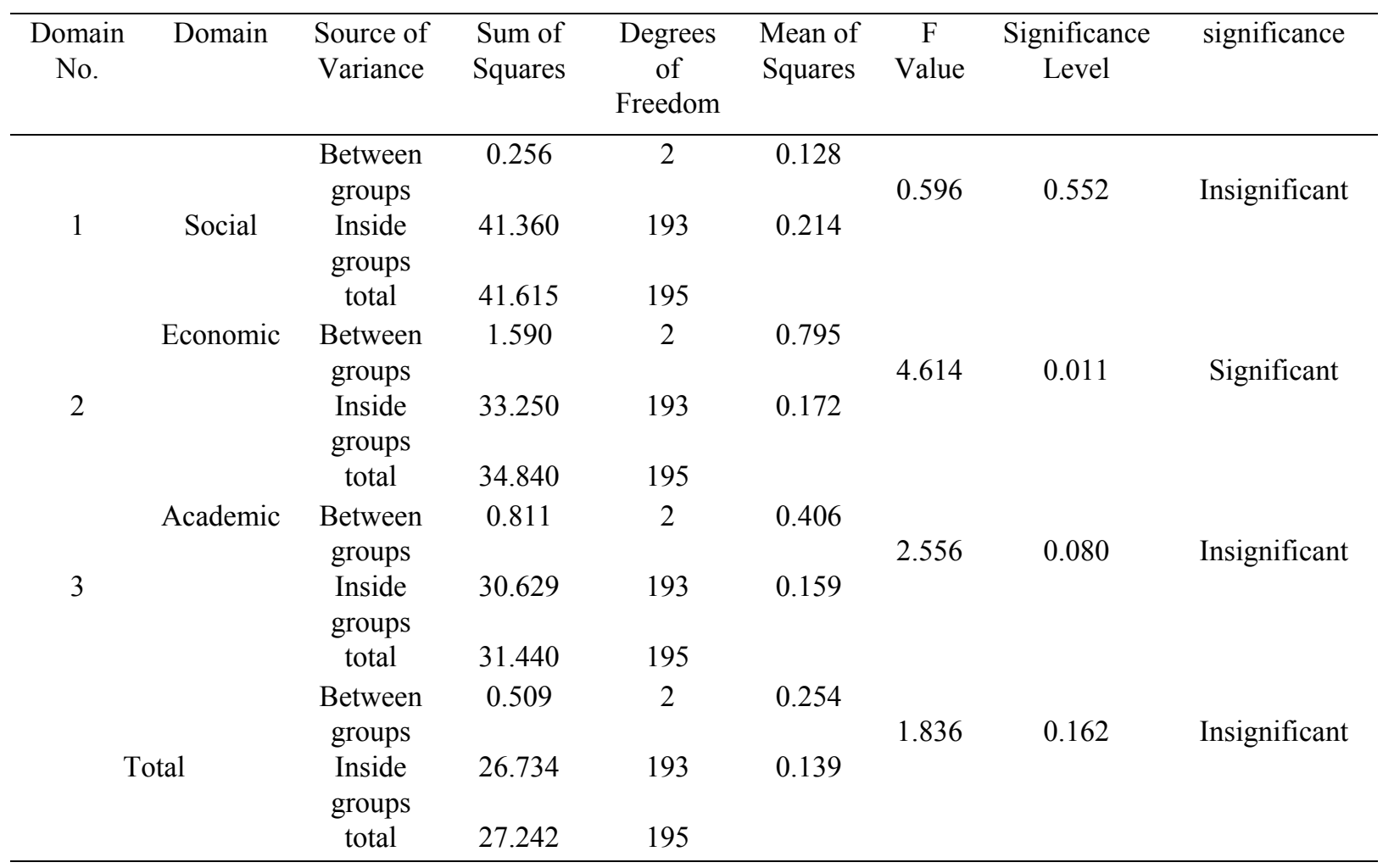

Level of significance $(\alpha \leq 0.05)$

Table 7 indicates the following:

- There are no significant differences at the level of $(\alpha \leqslant 0.05)$ within the 2 domains of social and academic, whereas the results of the economic domain shows the f-value (0.596) and the significance level $(0.552)$.

- There are statistically significant differences at the level of $(a \leqslant 0.05)$ for the sample within the economic domain according to the variable of university.

- There are no significant differences at the level of $(a \leqslant 0.05)$ in the total mean for the variable of university.

To reveal the position of the differences between the means for the economic field according to the variable of university, the researcher utilizes (L.S.D) test to compare means of the study fields according to this variable and as shown inTable 8. 
Table 8. Results of L.S.D post-test for the sample of the study within the economic field

\begin{tabular}{cccccc}
\hline Field & University & mean & Yarmouk & Mu'tah & Hashemite \\
\hline \multirow{3}{*}{ Economic } & Yarmouk & 3.62 & & -0.1279 & 0.1028 \\
& Mu'tah & 3.51 & & & 0.2307 \\
& Hashemite & 3.74 & & & \\
\hline
\end{tabular}

Level of significance $(\alpha \leq 0.05)$

Results that are related to (L.S.D) test for comparing the means according to the economic domain with regard to the variable of university and displayed in table (9) indicate the following:

Regarding the economic domain, there are statistically significant differences between the $2^{\text {nd }}$ level (Mu'tah) where $S=3.51$, and the $3^{\text {rd }}$ level (Hashemite) where $S=3.74$, and for the benefit of the $3^{\text {rd }}$ level, which means that the deanships' workers at the Hashemite university have got a prominent role in attracting students towards participating in activities more than other universities' workers.

The researcher ascribes that to the location of the Hashemite University which is set in the middle of the kingdom's cities, and doesn't cost the students high costs for transportation and food expenses. So more students take part in the activities than other universities, from the point of view of deanships' workers.

Third: Does this role of the workers in Students' Affairs Deanships at the Jordanian universities in attracting students towards participating in activities differ according to the variable of years of experience?

To answer this question, One-Way ANOVA was used to determine the existence of statistically significant differences for the role of deanships' workers in attracting students towards participating in activities according to the variable of years of experience.

Table 9. Means \& SDs for the study sample according to the variable of experience years

\begin{tabular}{cccccccccc}
\hline $\begin{array}{c}\text { Domain } \\
\text { No. }\end{array}$ & domain & \multicolumn{2}{c}{$1-5$ years } & \multicolumn{2}{c}{$6-10$ years } & \multicolumn{2}{c}{$11-15$ years } & \multicolumn{2}{c}{16 years \& more } \\
& & mean & SD & mean & SD & mean & SD & mean & SD \\
\hline 1 & Social & 3.95 & 0.44 & 3.81 & 0.48 & 3.92 & 0.48 & 3.84 & 0.45 \\
2 & Economic & 3.74 & 0.43 & 3.54 & 0.45 & 3.55 & 0.38 & 3.58 & 0.42 \\
3 & Academic & 3.61 & 0.44 & 3.44 & 0.46 & 3.51 & 0.35 & 3.46 & 0.36 \\
\multicolumn{2}{l}{ Entire } & 3.77 & 0.39 & 3.59 & 0.42 & 3.66 & 0.34 & 3.63 & 0.35 \\
\hline
\end{tabular}

Table 10 shows the following:

There are no statistically significant differences at the level of $(\alpha \leq 0.05)$ within the study fields because the f-value for the social domain was (0.917) and the significance level was $(0.436)$, whereas the f-value for the economic domain was (2.083) with a significance level of (0.104). As for the last domain, the academic, the value was $(1.698)$, and the significance level was $(0,169)$. The calculated f-value for the total average was (1.747), and the level of significance was (0.159).

The researcher ascribes that to the idea that the deanships' workers' evaluation of the students' participation in activities is not connected to their years of experience because they already have duties and programs for work through which they deal with all of the university students in general. Also, they are keen on implementing these duties and missions regardless to the number of experience years. They try to apply the activities' programs in accordance to the scheduled plans prepared by the deanships' administrations. 
Table 10. Results of one-way Anova for the sample according to experience years

\begin{tabular}{|c|c|c|c|c|c|c|c|c|}
\hline $\begin{array}{c}\text { Domain } \\
\text { No. }\end{array}$ & Domain & $\begin{array}{c}\text { Source } \\
\text { of } \\
\text { Variance }\end{array}$ & $\begin{array}{c}\text { Sum } \\
\text { of } \\
\text { Squares }\end{array}$ & $\begin{array}{l}\text { Degrees of } \\
\text { Freedom }\end{array}$ & $\begin{array}{c}\text { Mean } \\
\text { of } \\
\text { Squares }\end{array}$ & $\begin{array}{c}\mathrm{F} \\
\text { Value }\end{array}$ & $\begin{array}{c}\text { Significance } \\
\text { Level }\end{array}$ & significance \\
\hline \multirow[b]{2}{*}{1} & \multirow[b]{2}{*}{ Social } & $\begin{array}{c}\text { Between } \\
\text { groups }\end{array}$ & 0.585 & 3 & 0.195 & \multirow[t]{2}{*}{0.913} & \multirow[t]{2}{*}{0.436} & \multirow[t]{2}{*}{ Insignificant } \\
\hline & & $\begin{array}{l}\text { Inside } \\
\text { groups } \\
\text { total }\end{array}$ & $\begin{array}{c}41.03 \\
41.615\end{array}$ & $\begin{array}{l}192 \\
195\end{array}$ & 0.214 & & & \\
\hline \multirow[b]{2}{*}{2} & Economic & $\begin{array}{c}\text { Between } \\
\text { groups }\end{array}$ & 1.098 & 3 & 0.366 & \multirow[t]{2}{*}{2.083} & \multirow[t]{2}{*}{0.104} & \multirow[t]{2}{*}{ Insignificant } \\
\hline & & $\begin{array}{l}\text { Inside } \\
\text { groups } \\
\text { total }\end{array}$ & $\begin{array}{l}33.741 \\
34.84\end{array}$ & $\begin{array}{l}192 \\
195\end{array}$ & 0.176 & & & \\
\hline \multirow{3}{*}{3} & Academic & $\begin{array}{l}\text { Between } \\
\text { groups }\end{array}$ & 0.813 & 3 & 0.271 & \multirow[t]{2}{*}{1.698} & \multirow[t]{2}{*}{0.169} & \multirow[t]{2}{*}{ Insignificant } \\
\hline & & $\begin{array}{l}\text { Inside } \\
\text { groups } \\
\text { total }\end{array}$ & $\begin{array}{l}30.627 \\
31.44\end{array}$ & $\begin{array}{l}192 \\
195\end{array}$ & 0.16 & & & \\
\hline & & $\begin{array}{l}\text { Between } \\
\text { groups }\end{array}$ & 0.724 & 3 & 0.241 & 1.747 & 0.159 & Insignificant \\
\hline \multicolumn{2}{|c|}{ Total } & $\begin{array}{l}\text { Inside } \\
\text { groups } \\
\text { total }\end{array}$ & 26.518 & $\begin{array}{l}192 \\
195\end{array}$ & 0.138 & & & \\
\hline
\end{tabular}

Level of significance $(\alpha \leq 0.05)$

Fourth: Does this role of the workers in Students' Affairs Deanships at the Jordanian universities in attracting students towards participating in activities differ according to the variable of scientific qualification?

To answer this question, One-Way ANOVA was used to determine the existence of statistically significant differences for the influence of the variable of qualification on the role of deanships' workers in attracting students towards participating in activities.

Table 11. Means \& SDs for the study sample according to the variable of scientific qualification

\begin{tabular}{|c|c|c|c|c|c|c|c|c|c|}
\hline \multirow{2}{*}{$\begin{array}{l}\text { Domain } \\
\text { No. }\end{array}$} & \multirow[t]{2}{*}{ domain } & \multicolumn{2}{|c|}{ secondary } & \multicolumn{2}{|c|}{ diploma } & \multicolumn{2}{|c|}{ B.A degree } & \multicolumn{2}{|c|}{ Higher Education } \\
\hline & & mean & SD & mean & SD & mean & SD & mean & SD \\
\hline 1 & Social & 3.92 & 0.47 & 3.86 & 0.47 & 3.85 & 0.46 & 3.95 & 0.45 \\
\hline 2 & Economic & 3.74 & 0.45 & 3.56 & 0.44 & 3.57 & 0.39 & 3.60 & 0.44 \\
\hline 3 & Academic & 3.61 & 0.32 & 3.50 & 0.41 & 3.47 & 0.42 & 3.49 & 0.40 \\
\hline Entire & & 3.76 & 0.34 & 3.64 & 0.39 & 3.63 & 0.37 & 3.68 & 0.39 \\
\hline
\end{tabular}

Table 12 shows the following:

There are no statistically significant differences at the level of $(\alpha \leq 0.05)$ within the study fields because the f-value for the social domain was (0.487) and the significance level was (0.692), whereas the f-value for the economic domain was (1.502) with a significance level of (0.215). As for the last domain, the academic, the value was (1.012), and the significance level was $(0,389)$. The calculated $f$-value for the total average was (1.010), and the level of significance was (0.389).

The researcher ascribes that to the idea that the deanships' workers' evaluation of the students' participation in activities is not connected to their scientific qualification because they already have an identified job description that they have to follow and accomplish. Also, they have to implement the deanship's plan that goes in line with the university's policy which is drawn by the students' affairs dean who cooperates with the special administrative crew at the deanship who is responsible for managing the deanship. 
Table 12. Results of one-way Anova for the sample according to qualification

\begin{tabular}{|c|c|c|c|c|c|c|c|c|}
\hline $\begin{array}{l}\text { Domain } \\
\text { No. }\end{array}$ & Domain & $\begin{array}{c}\begin{array}{c}\text { Source } \\
\text { of } \\
\text { Variance }\end{array} \\
\end{array}$ & $\begin{array}{c}\begin{array}{c}\text { Sum } \\
\text { of } \\
\text { Squares }\end{array} \\
\end{array}$ & $\begin{array}{l}\text { Degrees of } \\
\text { Freedom }\end{array}$ & $\begin{array}{c}\text { Mean } \\
\text { of } \\
\text { Squares }\end{array}$ & $\begin{array}{c}\mathrm{F} \\
\text { Value }\end{array}$ & $\begin{array}{c}\text { Significance } \\
\text { Level }\end{array}$ & significance \\
\hline \multirow{3}{*}{1} & \multirow{3}{*}{ Social } & $\begin{array}{c}\text { Between } \\
\text { groups }\end{array}$ & 0.314 & 3 & 0.105 & \multirow[t]{3}{*}{0.487} & \multirow[t]{3}{*}{0.292} & \multirow[t]{3}{*}{ Insignificant } \\
\hline & & $\begin{array}{l}\text { Inside } \\
\text { groups }\end{array}$ & 41.301 & 192 & \multirow[t]{2}{*}{0.215} & & & \\
\hline & & total & 41.615 & 195 & & & & \\
\hline \multirow[b]{2}{*}{2} & Economic & $\begin{array}{c}\text { Between } \\
\text { groups }\end{array}$ & 0.799 & 3 & 0.266 & \multirow[t]{2}{*}{1.502} & \multirow[t]{2}{*}{0.215} & \multirow[t]{2}{*}{ Insignificant } \\
\hline & & $\begin{array}{l}\text { Inside } \\
\text { groups } \\
\text { total }\end{array}$ & $\begin{array}{l}34.041 \\
34.840\end{array}$ & $\begin{array}{l}192 \\
195\end{array}$ & 0.177 & & & \\
\hline \multirow{6}{*}{3} & Academic & $\begin{array}{c}\text { Between } \\
\text { groups }\end{array}$ & 0.489 & 3 & 0.163 & \multirow[t]{3}{*}{1.012} & \multirow[t]{2}{*}{0.389} & \multirow[t]{3}{*}{ Insignificant } \\
\hline & & $\begin{array}{l}\text { Inside } \\
\text { groups }\end{array}$ & 30.440 & 192 & 0.161 & & & \\
\hline & & total & 31.440 & 195 & & & \multirow{4}{*}{0.389} & \\
\hline & \multirow{3}{*}{ Total } & $\begin{array}{c}\text { Between } \\
\text { groups }\end{array}$ & 0.423 & 3 & 0.141 & \multirow[t]{3}{*}{1.010} & & \multirow[t]{3}{*}{ Insignificant } \\
\hline & & $\begin{array}{l}\text { Inside } \\
\text { groups }\end{array}$ & 26.819 & 192 & 0.140 & & & \\
\hline & & total & 27.242 & 195 & & & & \\
\hline
\end{tabular}

Level of significance $(\alpha \leq 0.05)$

\section{Conclusions}

1. The role of the students' affairs deanships' workers in attracting students towards participating in activities was high.

2. The findings of the study reveals no statistically significant differences for the variable of gender in the study's domains.

3. There are no statistically significant differences in the total average of the variable of university.

4. The findings of the study reveals no statistically significant differences for the entire average for the variable of years of experience within the domains of the study.

5. The role of the Hashemite university deanship workers is higher than other university's workers.

6. There are no statistically significant differences in the total average of the variable of qualification.

7. There is no connection between the variable of experience and the students' participation in activities since the worker applies programs that are prepared previously according to the plan set by the students' affairs deanship.

\section{Recommendations}

In light of the findings of the study, the researcher suggests the following:

1. Careful selection of the technical crews of administrators and supervisors working at students' affairs deanships since they deal with a very important section in society that needs special types of employees so as to generate productive members to the society.

2. Transferring the students' activities centre to the academic colleges of the university where each college allocates an office that is technically and administratively controlled by the deanship, and that is also concerned with the college activities (social, artistic, sportive, and cultural). This office has competent and specialized persons, and it provides the university institutions with distinguished members who represent it in occasions and events.

3. Holding specialized seminars and educational workshops for students and deanships' workers about the role of the students' activities in regulating, polishing and developing the student's personality to enable them cope with the university life and the life after graduation. 
4. Establishing a fund at the deanship called "supporting students' activities fund" for organizing and supporting the deanship's activities. The university allocates in its budget a special stipulation for supporting it, and it can also receive support and outside donations. It aims at covering the expenses of visits, trips and outside student's activities as well as providing some distinguished students with financial support.

\section{References}

Al-Bataineh, O., \& Al-Zu'bi, Z., \& Al-Hatamleh, M. (2008). The Role of Practicing Sportive Activities in Polishing the Jordanian Student's Personality. The Conference of the College of Physical Education. University of Jordan, Amman, Jordan.

Al-Farhan, I. (2000). Organizing the Education Sector in Jordan. Summaries of the Higher Education Conference in Jordan: Between Reality and Ambition. Zarqa University.

Al-Shra'a, M., \& Al-Zu'bi, Z., \& Al-Bataineh, O., \& Al-Rifa'ee, E. (2010). The Influence of Some Factors on the University Students' Participation in Different Activities. A Field Study for the Formal Universities Students. The Psychological and Educational Sciences Journal. Damascus University.

Al-Sukhun, A. H. A. (2001). Free Time \& Entertaining Activities Among the University of Jordan Students. Master Thesis, Jordan University.

Al-Toom, A. M. (2003). The Role of Social \& Psychological Counseling in Serving Students. The Conference of Students' Affairs Deanships. Zarqa Private University, Jordan.

Al-Zu'bi, Z., \& Abu Tabanja, A. A., \& Al-Hatamleh, M. (2007). The Influence of Practicing Students' Activities on Facing Some Students' Troubles from the Hashemite University Students point of view. Al-Najah University Journal for Researches, 21(4).

Al-Zu'bi, Z. (2004). The Influence of Some Social, Economic and Academic Factors on the Tendency of Aggressive Behavior among the Hashemite University Students. Unpublished dissertation, Arab Amman University for Higher Education, Amman, Jordan.

Al-Zyoud, K., \& Aranki, R. (2003). Students' Affairs: A new thought for a new generation. The Conference of Students' Affairs Deanships, Zarqa Private University, Jordan.

Bodi, Z. (2003). The Relationship between the Students' Affairs Deanships and the University Different Colleges, Deanships and Administrations. The Conference of Students' Affairs Deanships. Zarqa Private University, Jordan.

Deerani, E. (2003). The reasons Behind Students' Refrainment from Participation in Activities, Case study: Al-Shariqa University. The Conference of Students' Affairs Deanships, Zarqa Private University, Jordan.

\section{Copyrights}

Copyright for this article is retained by the author(s), with first publication rights granted to the journal.

This is an open-access article distributed under the terms and conditions of the Creative Commons Attribution license (http://creativecommons.org/licenses/by/3.0/). 